\title{
DISTRIBUTION AND HABITAT OF HELICARION RUBICUNDUS (PULMONATA: HELICARIONIDAE), A RARE LAND SNAIL
}

\author{
by Robert J. Tayior \\ (with one text-figure)
}

TAYLOR, R.J. 1991 (20:xii): Distribution and habitac of Helicarion rubicundus (Pulmonata: Helicarionidae), a rare land snail. Pap. Proc. R. Soc. Tasm. 125: 27-28. https://doi.org/10.26749/rstpp.125.27 ISSN 0080-4703. Forest Pracrices Unit, Forestry Commission, 30 Patrick Street, Hobart, Tasmania, Australia 7000.

Distriburion records and details of habitat are provided for Helicarion rubicundus, a land snail. This species was previously known only from one location. It was found to occur through much of the wet forest on Forestier Peninsula but to be rare within suitable habitat on Tasman Peninsula.

Key Words: land snail, Tasmania, pulmonate.

\section{INTRODUCTION}

In 1976, Dartnall and Kershaw (1976) described a new species of Helicarion in Tasmania, H. rubicundus. The specific name was chosen to draw attention to the colour of the animal, which is burgundy. The species has been referred to by the common name of the burgundy snail.

Helicarion rubicundus can be readily distinguished from its congener, $H$. cuvieri, by body colouration $(H$. rubicundus - burgundy, sometimes with a green tinge; H. cuvierigrey, greyish buff or white) and caudal mucus (H. rubicundus - red; H. cuvieri - yellow). The genus Helicarion is distinguished by the small, thin, transparent shell, which is convex to flat with a greatly enlarged body whorl. The body can only be partly withdrawn into the shell. Accessory lobes of the mantle partly cover the shell. The foot is posteriorly truncate.

The specimens on which the description of $H$. rubicundus were based came from a gully just north of Eaglehawk Neck on Forestier Peninsula and were collected in 1971. This is the only locality from which they were known. They had not been found in similar habitat on Tasman Peninsula despite intensive searches at several localities (K. Bonham, pers. comm.). The present study was undertaken to try to locate further populations of $H$. rubicundus and to gain an understanding of its habitat requirements.

\section{METHODS}

Searches for $H$. rubicunduswere undertaken on Forestier and Tasman Peninsulas on 8,18 and 19 July and 5 and 6 December 1989. Twenty-four sites on Forestier Peninsula and six sites on Tasman Peninsula were examined. At each site, searching was undertaken either until $H$. rubicundus was found or for a period ranging between thirty and ninety minutes.

\section{RESULTS}

\section{Distribution}

Sites searched and locations where H. rubicunduswere found are shown in figure 1. The species occurs at numerous locations on Forestier Peninsula but was found at only one site on Tasman Peninsula.

\section{Habitat Preferences}

The distribution of wet and dry sclerophyll forest in the study area is shown in figure 1 . No specimens were found in dry sclerophyll forest. On Forestier Peninsula, H. rubicunduswas found in 15 out of the 20 sites in wet forest that were searched, but in only one of the six wet forest sites on Tasman Peninsula. No factors associated with their absence from wet sites could be recognised. They were found close to creek lines, on slopes above creeks and on flatter ridge tops. Vegetation of these sites was typical of wet forests. Dominant eucalypts present were Eucalyptus obliqua, E. regnans and $E$. globulus. Common understorey species included Pomaderris apetala, Bedfordia salicina, Notelaea ligustrina, Blechnum wattsii, Dicksonia antarctica, Atherosperma moschatum, Melaleuca squarrosa, Gahnia grandis, Olearia argophylla, Coprosma quadrifida, Zieria arborescens, Lepidospermaelatius, Tasmannia lanceolata, Leptospermum lanigerum and Acacia melanoxylon. The undergrowth was mostly open, with a welldeveloped leaf litter. However, specimens were also collected from areas where Gahnia clumps were frequent. Snails were found in 20-year-old regeneration resulting from clearfelling, previously cut-over forest and old growth.

\section{Sheltering Sites}

Helicarion rubicundus is normally inactive during the day, and hence situations in which they occur represent sheltering sites. Individuals were found under rocks, under bark on fallen trees, in litter accumulated at the base of trees or sedges and in curled pieces of thin bark. By far the most rewarding site was curled bark. The snails appeared to prefer clean 


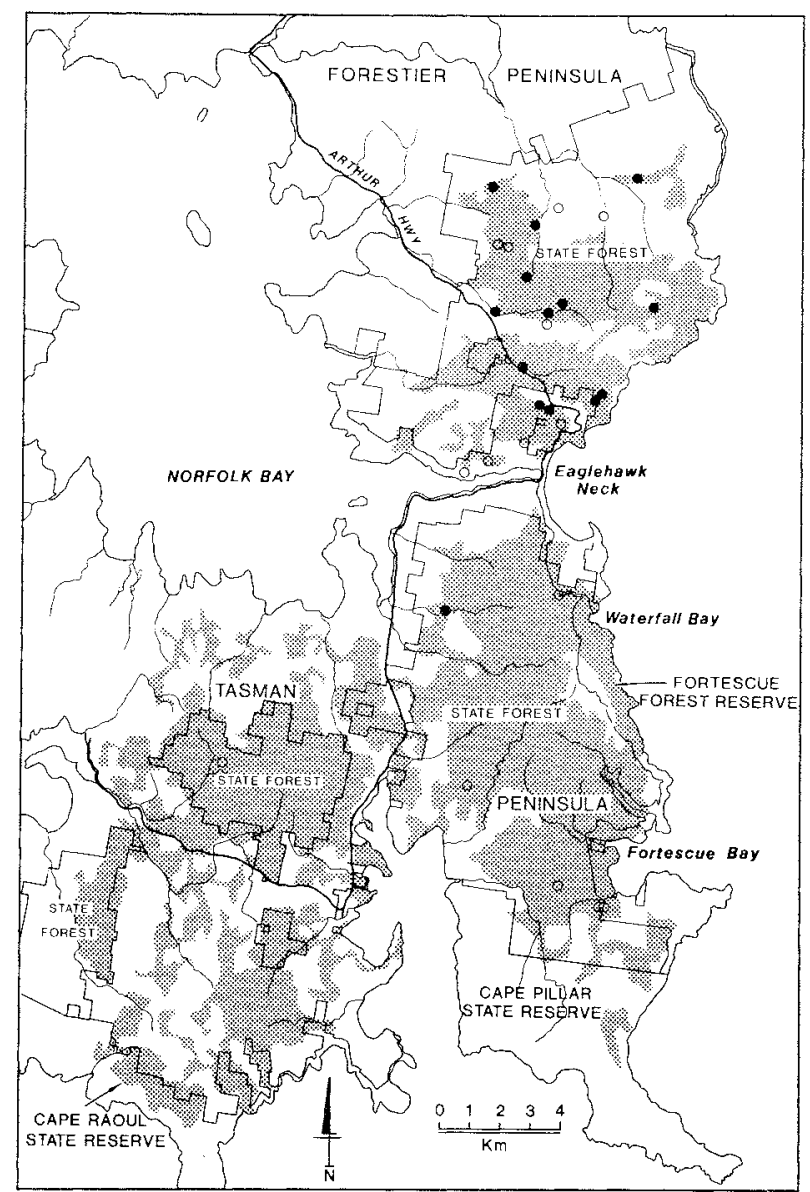

FIG. 1 - Distribution of suitable habitat for Helicarion rubicundus. $O=$ wet sclerophyll forest, $\bullet=$ locations where $\mathrm{H}$. rubicundus was found, $\mathrm{o}=$ locations where searches were unsuccessful.

pieces of bark rather than old, dirty, decaying pieces. Curled eucalypt bark is a typical shelter for Helicarion, Cystopelta and some other small species in many parts of Tasmania $(R$. Kershaw, pers. comm.).

\section{DISCUSSION}

Helicarion rubicundus shows a distinct preference for wet forest. It was found to be widespread within these forests on Forestier Peninsula. However, the species was not found at all such sites. Whether it would have been found with further searching is not known, but the species did appear to differ in abundance between localities in suitable habitats. Further work would be needed to quantify and explain these differences. One site where the species appeared to be plentiful was in 20-year-old silvicultural regrowth. H. rubicundus was also noted in other sites with young forest and in areas where the presence of stumps indicated past selective logging.

Helicarion rubicundus seems to have suffered a decline in its type locality. An intensive search here failed to locate any specimens. A single individual was found further up the gully. R. Kershaw (pers. comm.) has noted that there has been a considerable increase in shrub cover at the type locality since the species was first discovered there.
On Tasman Peninsula, H. rubicundus seems to be much rarer and/or more restricted than on Forestier Peninsula. Other searches at several locations on Tasman Peninsula have also failed to reveal any $H$. rubicundus (K. Bonham, pers. comm.).

Helicarion cuvieri was found in most of the sites where $H$. rubicundus was located. It also occurred at other sites where no $H$. rubicundus was found, including some locations in dry sclerophyll forest. $H$. cuvieri thus appears to tolerate a wider range of environments than does $H$. rubicundus. There was no obvious inverse relationship between the apparent densities of the two species which might have been expected if competition between them was occurring. At the site with silvicultural regrowth, both species appeared to be abundant.

This study has found $H$. rubicundus to be much more widespread than the single locality from which it was previously known. Its overall range is still quite restricted and it ranks as one of the rarest of the Tasmanian terrestrial snails on a statewide basis (Smith \& Kershaw 1981). It is certainly more restricted than Anoglypta launcestonensis (Kershaw 1988), a species whose conservation status has received much attention. Most of the range of $H$. rubicundus is encompassed by State forest. Populations appear not to have been disadvantaged by past logging operations. However, further monitoring of the effects of logging is warranted, given the rarity of the species. It is likely that a wide section of forest along the eastern coastline of Forestier Peninsula will remain unlogged (see maps in Williams et al. 1990 and Taylor 1990). It, therefore, appears likely that the species will remain secure for the foreseeable future.

\section{ACKNOWLEDGEMENTS}

Ron Kershaw verified my identification of Helicarion rubicundus. I would like to thank Ric Dowling for accommodation and his interest in the work. Bill Brown prepared figure 1. Kevin Bonham and Bill Brown helped with field work. R.C. Kershaw, B.J. Smith and M. Brown provided comments on a previous draft. The study was funded by the Forestry Commission.

\section{REFERENCES}

DaR'T'NALL, A.J. \& Kershiaw, R.C., 1976: Description of a new species of Helicarion (Stylommatophora: Helicarionidae) in Tasmania. Rec. Q. Vict. Mus. 62: 1-18.

KtrshHAw, R.C., 1988: A study of the Caryodidae (Pulmonata) Part 1. Anoglypta launcestonensis (Reeve 1953). Rec. Q. Vict. Mus. 93: 1-24.

SMITH, B.J. \& KeRSHAW, R.C., 1981: TASMANIAN LAND AND FRESHWATER MOLLUSCS. Fauna of Tasmania Handbook 5. University of Tasmania, Hobart.

TAYLOR, R.J., 1990: FAUNA MANUAL. Forestry Commission, Hobart.

Whiliams, K., Duncan, F. \& Taylor, R., 1990: Biological conservation in Tasmania's production forests. Tasforests 2 : $73-78$.

(accepted 3 May 1991) 